\title{
Psychoactive Bath Salts and Neurotoxicity Risk
}

\section{Psikoaktif Banyo Tuzları ve Nörotoksisite Riski}

\author{
(D) Beril ALTUN*, (D) İsmet ÇOK \\ Gazi University, Faculty of Pharmacy, Department of Pharmaceutical Toxicology, Ankara, Turkey
}

\begin{abstract}
Synthetic cathinones are new designer drugs that possess hallucinogenic and psychostimulant properties, and are designed to mimic the effects of illegal substances such as cocaine, amphetamines, and 3.4-methylenedioxymethamphetamine (ecstasy) and to produce rewarding effects, circumventing existing laws and penalties. Synthetic cathinones, also referred to as 'bath salts', have become popular particularly among young people since the mid-2000s. Similar to other psychomotor stimulants, synthetic cathinones have the potential to increase monoamine concentration in the synaptic cleft by targeting the plasma membrane transporters of dopamine, norepinephrine, and serotonin. Because of their structural similarities to amphetamines, it has been suggested that synthetic cathinones may have a neurotoxicity profile similar to that of their amphetamine congeners. Therefore, it has been hypothesized that synthetic cathinones may induce neurotoxicity on monoamine nerve endings in the striatum, hippocampus, and cortex. To date, with regard to synthetic cathinone neurotoxicity, parameters such as monoamine depletion, biosynthetic enzyme inhibition, cytotoxicity, generation of reactive oxygen species, pro-oxidation status, and the ability to induce neuroinflammation were investigated in both in vitro and in vivo experimental studies. Compared with amphetamines, synthetic cathinones appear to have more moderate effects than their amphetamine congeners in terms of neurotoxic effects. However, many synthetic cathinone users take these substances simultaneously with other substances such as benzodiazepines, amphetamines, ecstasy, tetrahydrocannabinol, and ethanol and this abuse can modify their neurotoxic effects. Hence, it is important to understand the underlying mechanism of early neurotoxic effects in case of polysubstance use. In this review, we aimed to present up-to-date information on the abuse potential of synthetic cathinones, their legal status, mechanism of action, and particularly their neurotoxic effects.
\end{abstract}

Key words: Psychoactive, hallucinogen, bath salts, synthetic cathinones, neurotoxicity

öz

Sentetik katinonlar, mevcut yasa ve cezaları atlatabilmek amacıyla, kokain, amfetamin ve 3,4-metilendioksimetamfetamin (ekstazi) gibi yasadışı maddelerin etkilerini taklit etmek ve benzer ödüllendirici etkiler yaratmak üzere geliştirilmiş halüsinojenik ve psikostimülan özellikte yeni tasarlanmış yasadışı maddelerdir. Banyo tuzları olarak da bilinen sentetik katinonlar, 2000'li yılların ortalarından itibaren özellikle genç bireyler arasında popüler hale gelmeye başlamıştır. Diğer psikomotor uyarıcılara benzer şekilde, sentetik katinonlarda, dopamin, norepinefrin ve serotoninin plazma membran taşıyıcılarını hedef alarak sinaptik aralıktaki monoamin konsantrasyonunu arttırmaktadır. Amfetaminlere olan yapısal benzerlikleri nedeniyle, sentetik katinonların amfetamin homologları ile benzer nörotoksisite profiline sahip olabileceği düşünülmüștür. Bu nedenle, sentetik katinonların striatum, hipokampus ve kortekste monoamin sinir uçları üzerinde nörotoksisiteyi indükleyebileceği hipotezi öne sürülmüștür. Şimdiye dek sentetik katinonların nörotoksisitesi ile ilgili olarak yapılan in vitro-in vivo deneysel çalışmalarda, monoamin deplesyonu, biyosentetik enzim inhibisyonu, sitotoksisite, reaktif oksijen türlerinin oluşumu, pro-oksidasyon durumu ve nöroenflamasyon indükleme yeteneği gibi parametreler incelenmiştir. Sentetik katinonların nörotoksik etkiler açısından amfetamin homologlarından daha ılımlı olduğu görülmektedir. Ancak, pek çok sentetik katinon kullanıcısının bu maddeleri benzodiazepinler, amfetaminler, ekstazi, tetrahidrokannabinol ve etanol gibi diğer yasal olmayan ilaç veya bağımlılık yapıcı maddelerbirlikte almaktadır. Çünkü bu maddelerin nörotoksik etkileri değil, bu maddeler, sentetik katinonların nörotoksik etkilerini modifiye edebilmektedir. Bu nedenle, çoklu madde maruziyeti durumundaki erken nörotoksik etkilerin altında yatan mekanizmaların anlaşılması önemlidir. Bu derlemede, sentetik katinonların suistimal potansiyeli, yasal durumları, etki mekanizmaları ve özellikle nörotoksik etkileri hakkında güncel bilgi sunulması amaçlanmıştır.

Anahtar kelimeler: Psikoaktif, halüsinojen, banyo tuzları, sentetik katinonlar, nörotoksisite

\section{INTRODUCTION}

Synthetic cathinones are a subgroup of new psychoactive substances (NPSs) that possess hallucinogenic and psychostimulant properties and are designed to mimic the effects of illegal substances such as cocaine, 3.4-methylenedioxymethamphetamine (MDMA), and other amphetamines, circumventing existing laws. NPSs, or to use the other term 'designer drugs', are intentionally mislabeled and marketed as bath salts, fertilizers (although they have no such purpose), plant food, laboratory chemicals, or reagents and are marked as 'not for human consumption' or 'not tested for danger/toxicity' to avoid criminal liability. 2,3 Synthetic cathinones are one of the most commonly found psychoactive substances in these designer drug mixtures.

*Correspondence: E-mail: berilaltun@gmail.com, Phone: +90 5068201282 ORCID-ID: orcid.org/0000-0003-3083-9854

Received: 05.11.2018, Accepted: 06.12.2018

๑Turk J Pharm Sci, Published by Galenos Publishing House. 
Bath salts contain one or more synthetic cathinone derivates. The most popular bath salt constituents are 4-methylcathinone (mephedrone), 3.4-methylenedioxymethcathinone (methylone), and 3.4-methylenedioxypyrovalerone (MDPV). In point of fact, these compounds have no legitimate use as a bath additive in these products. ${ }^{4}$

Synthetic cathinones are usually a white, amorphous or crystalline powder, used by oral, rectal routes, injection, or inhalation. ${ }^{5}$ Some synthetic cathinone derivates also can be smoked or used as 'vapin' in e-cigarette-like devices. ${ }^{6}$ Synthetic cathinones, also referred to as 'bath salts', have become popular particularly among young individuals since the mid-2000s. ${ }^{4}$ In recent years, synthetic cathinones have increased in both supply and demand in every corner of the world. Because they are known as 'legal alternatives' to illicit drugs, there has been a dramatic increase in sales. Another reason that has made bath salts popular and widespread is the fact that they are easily accessible on the web. ${ }^{7}$ Drug trade through the cryptomarket on the web, called the Darknet, allows users to anonymously buy drugs. According to the United Nations Office on Drugs and Crime, while drug trafficking over the Darknet remains small, there was an increase in drug transactions of some $50 \%$ annually between 2013 and $2016 .^{8}$

Low doses of synthetic cathinones cause euphoria and alertness; however, high doses or chronic use can cause serious adverse effects such as hallucination, psychosis, delirium, hyperthermia, tachycardia, renal failure, and ischemia. Similar to other psychomotor stimulants, synthetic cathinones increase monoamine concentration in the synaptic cleft by targeting the plasma membrane transporters of dopamine (DAT), norepinephrine (NET), and serotonin (SERT). Induction of dopaminergic transmission suggests that they have a high potential for addiction. Because of their structural similarities with amphetamines, attempts have been made to develop many synthetic cathinone derivates as anorectics, central nervous system stimulants, or antidepressants, but the problem of addiction has hindered their clinical use..$^{9,10}$

Synthetic cathinones could physically harm users, which could also pose public health threats such as violence and irresponsible driving. Due to the health risks posed by bath salts, certain synthetic cathinones such as mephedrone, methylone, and MDPV have been made illegal in many countries. Even though they are seen as a legal alternative by users, their legal situation rapidly changes and differs among countries.1 The illegal availability of popular synthetic cathinones in many countries has led to the synthesis of new cathinone derivatives with minor modifications of their functional groups. This leads to a great diversity of product composition even within the same brand. ${ }^{12}$ The replacement of synthetic cathinones with newly developed cathinone derivatives causes a major problem in terms of the drug policy. The major problem is theoretically many structural variants of the cathinone are possible. ${ }^{13}$ The number of synthetic cathinones reported in 2008 was 8 , but this had increased to 68 by the end of 2014. The cumulative number reported to the European Monitoring Center for Drugs and Drug Addiction between 2005 and 2016 was 118. The total number reached 128 by $2017 .^{14}$

The gradual increase in the number of new derivatives makes it difficult to detect synthetic cathinones in biological specimens with routine toxicological tests. Since synthetic cathinones are a new chemical class, they cannot be determined by conventional techniques. The low specificity of immunoserological tests causes false-positive results. Qualitative and quantitative analyses of synthetic cathinones require more sensitive techniques and equipment such as gas chromatographymass spectrometry (GC-MS) or liquid chromatography- mass spectrometry (LC-MS). Due to the challenges with routine imaging techniques, the rate of use in subpopulations such as military personnel is still increasing in some countries. ${ }^{15}$ No global data are available, but the prevalence of mephedrone abuse among European adults aged 16-59 was estimated to have reached $0.5 \%$ in 2012-2013. ${ }^{14}$ In 2010 and 2011, there were a total of 362 calls made to the Texas Poison Center due to synthetic cathinone intoxication; $84.5 \%$ were over 20 years of age, $74 \%$ were male patients, $47.8 \%$ were exposed via inhalation, and $28.7 \%$ only by oral route. ${ }^{15}$

The most commonly seized synthetic cathinones in Europe were $\alpha$-pyrrolidinovalerophenone ( $\alpha$-PVP), 3-methylmethcathinone, ethylone, 4-chloromethcathinone, and pentedrone in 2015.16 In recent years, a second-generation synthetic cathinone derivative, $\alpha$-PVP, has rapidly gained popularity. $\alpha-P V P$, or 'flakka' to give it its street name, is a synthetic cathinone derivate bearing a pyrrolidine ring, colloquially called the 'zombie drug' due to the unpredictably bizarre and erratic behavior seen in its users. Recently, flakka abuse has been seen in Turkey, where it is classified as an illegal substance. ${ }^{17,18}$ A great handicap regarding $\alpha$-PVP abuse is its legal/under control status in some European and United Nations member states, e.g., Belgium, Denmark, Spain, Bulgaria, and Japan. ${ }^{19}$

The underlying mechanisms of the behavioral effects of cathinone analogues are not the same in all synthetic cathinone compounds; they depend on the chemical composition, function, and their selectivity on DAT/NET/SERT. The growing body of information on the neurotoxicity of synthetic cathinones justifies a review on the neurotoxicity of the frequently used synthetic cathinones.

\section{CHEMICAL STRUCTURE AND PROPERTIES}

Synthetic cathinones are the structural analogues of amphetamines and are chemically referred to as $\beta$-ketone analogues because of the carbonyl $(=0)$ group in $\beta$ carbon. The common pharmacophore group responsible for the biological effect seen in amphetamine, MDMA (ecstasy), and cathinones is phenethylamine, represented in Figure $1 .{ }^{20}$

The substitutional regions of synthetic cathinones are $\alpha$ and $\beta$ carbon. The length of the substitution at the $\mathrm{N}$-terminus varies within itself. MDPV and its derivatives differ from other derivates by the presence of the nitrogen-containing pyrrolidine ring. ${ }^{4}$ There is no scientific classification of 
synthetic cathinones; however, substituted cathinones can be classified as pyrrolidine-bearing/not pyrrolidine-bearing derivatives (Figure 2).

MDPV is structurally similar to pyrovalerone, the psychoactive drug used in the treatment of chronic lethargy. ${ }^{3}$ Pyrovalerone cathinones (MDPV and $\alpha$-PVP) are highly lipophilic compared with other derivates, thus having high blood-brain barrier (BBB) penetration/transition and a high volume of distribution. This results in longer plasma and tissue half-lives. ${ }^{21}$ The presence of electrophilic groups such as fluorine and the length of carbon substitution at the $\mathrm{N}$-terminus increase the lipophilic nature of synthetic cathinone analogues.

\section{MECHANISM OF ACTION}

The underlying mechanism of the behavioral and physiological effects of synthetic cathinone derivates is not fully understood yet. In general, synthetic cathinones increase the monoamine concentration in the synaptic cleft. The monoamine increase in the synaptic region mediates the stimulatory and hallucinogenic effects of synthetic cathinones. .,10,22 $^{2}$

Similar to other psychomotor stimulants, synthetic cathinones target plasma membrane DAT, NET, and SERT. ${ }^{4}$ Two distinct mechanisms mediate the increase in monoamine concentration in the synaptic cleft. In the first mechanism, as in amphetamines, it stimulates non-exocytic neurotransmitter release (secretory agents/substrates) by inhibiting the vesicular monoamine transporter-2 (VMAT2) and reversing the transporter influx. Substrates can stimulate neurotransmitter release from the cytosolic pool or synaptic vesicles. Monoamine neurotransmitters are packed into synaptic vesicles with the VMAT2. Since VMAT2 functions as a proton-monoamine antiporter, the change in the intravesical $\mathrm{pH}$ value disrupts the ability of VMAT2 to carry monoamines, thereby inhibiting vesicular storage of monoamines. Substrates such as MDMA alter the $\mathrm{pH}$ gradient required for VMAT2-mediated monoamine accumulation. In the second mechanism, as in cocaine, they inhibit the uptake of neurotransmitters from the synaptic cleft by inhibiting plasma membrane transporters, which are responsible for the uptake of NE and 5-HT as well as DA (reuptake inhibitors/blockers). ${ }^{22,23}$ Substrates and blockers differ in terms of their acute and chronic effects. ${ }^{4}$ Substrates can cause permanent damage to monoamine neurons by the loss of functional transporters and neurotransmitter depletion. ${ }^{24}$

Synthetic cathinones may act as an inhibitor or as a substrate (as an inhibitor on single transporter/more than one transporters or as a substrate on single transporter/more than one transporters) on DAT, NET, and/or SERT.13 The underlying mechanism of the physiological and behavioral effects of synthetic cathinones differs from agent to agent depending on chemical composition, function (secretory agent or reuptake inhibitor), and DAT/NET/SERT selectivity. This shows that synthetic cathinone analogues have a complex mechanism. Mephedrone is a nonselective substrate and stimulates the non-exocytotic release of NE, 5-HT, and DA. MDPV is a potent blocker of the DAT and NET, and also has a slight effect on the SERT. 4,25 Therefore, mephedrone and MDPV act via different mechanisms. When administered in combination, while MDPV blocks their re-uptake, mephedrone increases the concentration of neurotransmitters in the synaptic cleft. MDPV is 30-50 times more potent as a DA reuptake inhibitor than cocaine. Therefore, the combined use of mephedrone and MDPV causes effects resembling those of methamphetamine following cocaine intake, but with a more potent trend. ${ }^{13}$

To date, a few synthetic cathinone compounds' mechanisms of<smiles>NCCc1ccccc1</smiles>

I-Phenethylamine<smiles>CNC(C)C(=O)c1ccc(C)cc1</smiles>

IV-Mephedrone<smiles>CCCC(C(=O)c1ccc2c(c1)OCO2)N1CCCC1</smiles>

VI-3,4-methylenedioxypyrovalerone (MDPV)<smiles>CC(N)Cc1ccccc1</smiles>

II-Amphetamine<smiles>CC(N)C(=O)c1ccccc1</smiles>

\section{III-Cathinone}<smiles>CNC(C)C(=O)c1ccc2c(c1)OCO2</smiles><smiles>CCCC(C(=O)c1ccccc1)N1CCCC1</smiles>

VII- a-pyrrolidinovalerophenone ( $\alpha-P V P)$

Figure 1. Chemical structure of phenethylamine, amphetamine, cathinone, and other synthetic cathinone derivates ${ }^{20}$ 
action have been defined in detail. Many synthetic cathinone derivates are still in the process of being researched. Although researchers have made some progress on the structure-activity relationship of synthetic cathinones, further research is needed to predict the behavioral effects of new derivatives.

\section{NEUROTOXICITY}

Due to synthetic cathinones differing in terms of their mechanism and potential for causing changes in the extracellular concentrations of DA, NE, and 5-HT, their mood swing effects, toxicity, and dependence potentials are also divergent. Therefore, the toxicity of each synthetic cathinone should be assessed separately., ${ }^{9,26}$

The neurotoxicity induced by amphetamines has been studied in detail in humans and animals. In these studies, several parameters such as neuroinflammation-inducing ability, oxidative stress, cytotoxicity, neurotransmitter system dysregulation, and changes in monoamine transporter levels and receptors were evaluated. ${ }^{27}$

Methamphetamine is one of the best-known compounds for its neurotoxic effects at the dopamine nerve endings in the striatum. It has been demonstrated that MDMA causes long-term 5-HT depletion at monoamine nerve endings. Amphetamine neurotoxicity includes inhibition of biosynthetic enzymes of monoamines, i.e. tryptophan hydroxylase (TPH2) and tyrosine hydroxylase (TH), DAT and SERT inactivation, diminished VMAT2 function, degeneration and apoptosis in unmyelinated axons at the nerve endings, prolonged DA, and 5-HT depletion. ${ }^{28}$

Because of their structural similarities to amphetamines, it has been suggested that synthetic cathinones may have a neurotoxicity profile similar to that of their amphetamine congeners. Hence, synthetic cathinones may cause neurotoxicity at the monoamine nerve endings in the striatum, hippocampus, and cortex. ${ }^{29}$ Parameters such as monoamine depletion, biosynthetic enzyme inhibition, cytotoxicity, generation of reactive oxygen species (ROS), and ability to induce neuroinflammation of synthetic cathinones were compared with amphetamines. Researchers have reached the conclusion that synthetic cathinones are more moderate than their amphetamine congeners in terms of these toxic effects. ${ }^{27}$

The neurotoxicity studies of synthetic cathinone compounds are generally directed to mephedrone toxicity. ${ }^{30-36}$ The neurotoxicity induced by mephedrone has not been fully elucidated yet. Despite the considerable evidence that mephedrone is dangerous, how it plays a role in the central nervous system is controversial. While no damage to dopaminergic nerve endings or no change in monoamine levels in the synaptic cleft was stated in parts of studies with animal models, ${ }^{31,32}$ in some other studies decreases in DAT and SERT function and damage at dopaminergic/serotonergic nerve endings were observed. ${ }^{30,33}$

Many synthetic cathinone users take these substances simultaneously with other drugs such as benzodiazepines, other amphetamines, ecstasy, tetrahydrocannabinol, and ethanol. ${ }^{37}$ It is known that $95 \%$ of synthetic cathinone users are also alcohol consumers at the same time. How ethanol modifies the neurotoxicity induced by mephedrone remains unknown but researchers found that ethanol exacerbated the decrease in DAT and TH levels in the frontal cortex as well as the reduction in SERT and TPH-2 levels by 2 -fold in CD1 mice. Moreover, this decrease was correlated with a 2-fold increase in lipid peroxidation levels. ${ }^{35}$

In another study with pregnant rats, repeated exposure to

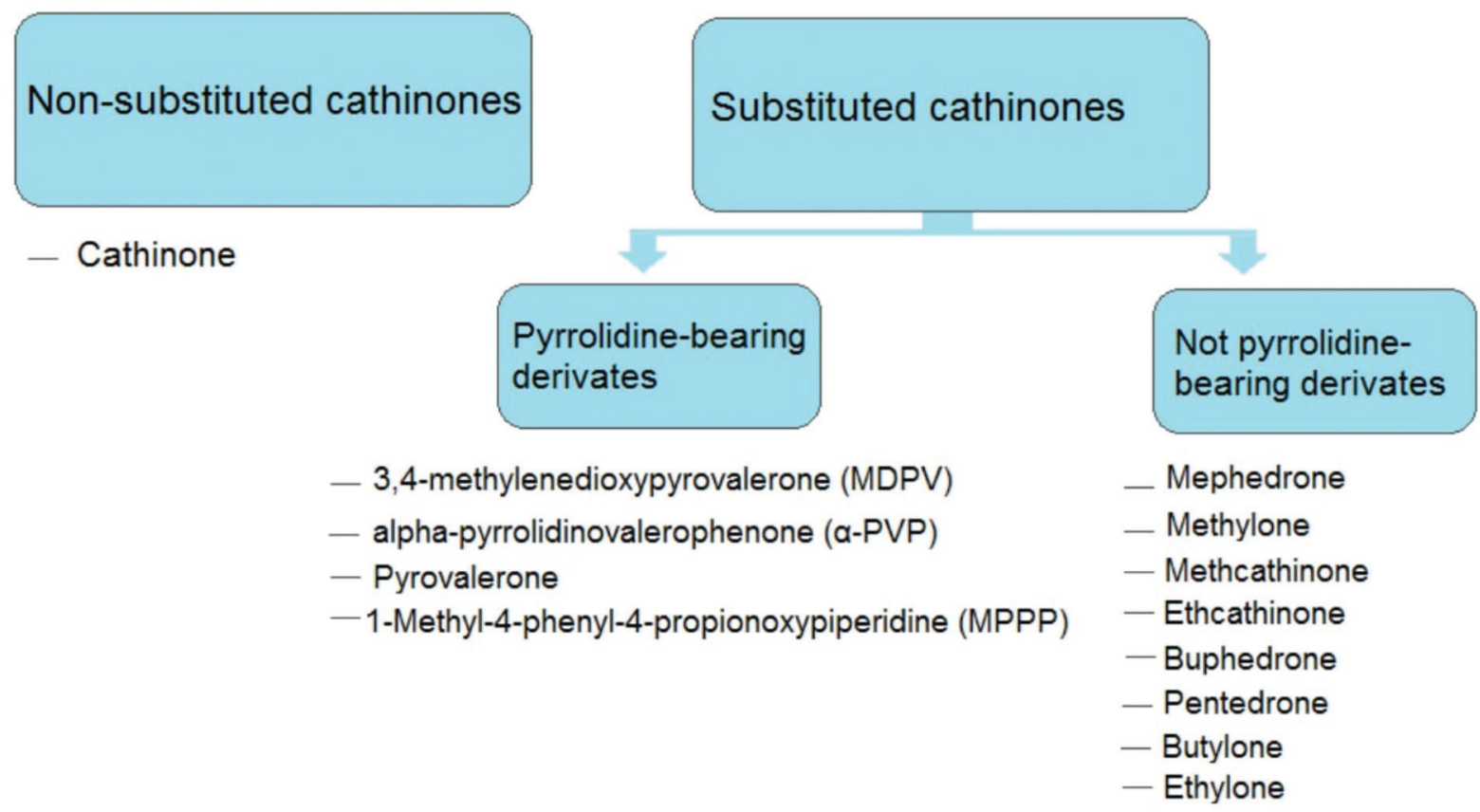

Figure 2. Classification of synthetic cathinone analogues 
mephedrone during pregnancy caused low birth weight and increased risk of stillbirth. Moreover, it has been shown that repetitive use of mephedrone is associated with hippocampal damage and disrupts learning and memory processes. ${ }^{36}$

An increase in cytotoxicity and lipid peroxidation parameters by inducing oxidative stress in the frontal cortex was observed after mephedrone application in rats. ${ }^{34}$ In addition to brain tissue, mephedrone induces oxidative stress also in the kidneys, heart, liver, and spleen of mice. ${ }^{38}$

There are also studies about MDPV and methylone neurotoxicity. ${ }^{29,33,39-43}$ In a study comparing the neurotoxicity of methylone and MDPV with that of MDMA, a concentrationdependent decrease in cell viability was observed in differentiated and undifferentiated dopaminergic cells (MDPV MDMA>methylone). Differentiated cells were found to be more vulnerable than undifferentiated cells. As a mechanism of neurotoxicity, findings of increased intracellular ROS and NO levels, glutathione depletion, elevated levels of oxidative glutathione, deterioration of mitochondrial membrane potential, and intracellular ATP depletion indicate oxidative stress and mitochondrial dysfunction, resulting in cell death. Condensed chromatin, pyknotic cell formation, and caspase $-3,-8$, and -9 activations suggest that apoptosis is the mechanism of cell death induced by methylone and MDPV. ${ }^{39}$

Microglia and astrocytes are primary inflammation modulators in the central nervous system. Increased glial-based cytokines in chronic neuroinflammation cause toxic effects in vulnerable neurons. The studies on the neuroinflammation-inducing ability of synthetic cathinones are controversial. Some in vivo studies have not found any evidence for astroglial activation in the striatal or cortical regions after mephedrone administration. ${ }^{33,34,44}$ However, increased glial-specific marker (glial fibrillary acidic protein) immunoreactivity in the hippocampus 7 days after mephedrone administration at recreational dose was observed. ${ }^{45}$

In a recent study, it has been found that methylone neurotoxicity is related to posology. Furthermore, increased immobility in animals indicates depression-like effects. ${ }^{40}$ Neurochemical/enzymatic changes in rats following methylone administration at the recreational dose $(20 \mathrm{mg} / \mathrm{kg})$ were tested and hyperthermia developed 30 min after dosing. In addition, serotonergic impairment accompanied by astrogliosis in the frontal cortex was observed, but no significant neurotoxicity was found in the dopaminergic system. The study was conducted at a high ambient temperature $\left(26 \pm 1^{\circ} \mathrm{C}\right)$ to simulate the hot conditions in dance clubs where methylone was used. ${ }^{41}$ Time- and concentration-dependent ROS formation, reduction in cellular proliferation rate (only at high concentrations), apoptosis induction, and necrosis have been observed in human dopaminergic SH-SY5Y cells regarding the cytotoxic effects of MDPV. ${ }^{42}$ Induction of ROS formation may be the underlying mechanism of the early toxic effects of MDPV.

Various studies have reported adverse effects of methamphetamine and MDMA on the BBB. When comparing the toxic effects of MDPV on the BBB with those of methamphetamine and MDMA, MDPV was found to be more toxic than its amphetamine homologues. MDPV showed cytotoxic effects at all concentrations. There was a decrease in cellular proliferation at $1 \mathrm{mM}$ concentration, an increase in reactive oxygen and nitrogen species at all concentrations, and change in endothelial morphology at $\geq 0.5 \mathrm{mM}$ concentrations. ${ }^{43}$ These data suggest that synthetic psychostimulants may be toxic to the monoaminergic system as well as to the BBB through different mechanisms.

Another derivative that has attracted attention in recent years is $\alpha$-PVP. Awareness of the case reports associated with $\alpha$-PVP ingestion is increasingly important due to severe toxic effects and fatal intoxications. ${ }^{6,46-48}$ Although the exact mechanism of $\alpha$-PVP remains unclear, it is known that $\alpha$-PVP is designed to cause the brain to become flooded with dopamine. Due to its structural similarity to MDPV, $\alpha$-PVP was suggested to be a NE-dopamine reuptake inhibitor and dopamine releaser, therefore causing an increase in locomotor activity. ${ }^{49}$ However, studies investigating the potential neurotoxicity of $\alpha$-PVP in the literature are very few. We came across one molecular mechanistic study about $\alpha$-PVP. $\alpha$-PVP modulated immediate early gene expression such as Arc/Arg3 and c-fos in the frontal cortex, striatum, and hippocampus in that study, thus indicating this drug has an impact on brain homeostasis. ${ }^{50}$ Still, more research is needed with regard to the neurotoxic effects of $\alpha$-PVP in different brain regions.

\section{DISCUSSION AND CONCLUSION}

Synthetic cathinones represent a broad class of pharmacologically active compounds that can cause numerous effects via different mechanisms. Synthetic cathinones are a global threat with rapidly increasing abuse rates. Due to these substances differing in terms of their mechanism and potency, their mood-altering effect, toxicity, and dependence potentials are also divergent. Therefore, each synthetic cathinone compounds should be evaluated separately.

In the literature, studies are generally directed to synthetic cathinones' psychostimulant and locomotor stimulant effects, neurocognitive performance, and memory, while neurotoxicity studies are limited. The neurotoxicity of synthetic cathinones has not been fully elucidated yet. The neurotoxic effects of synthetic cathinones on the serotonergic and dopaminergic system are controversial. Differences in experimental design, such as temperature and animal species, make it difficult to compare the results. In some animal model studies, no damage or changes in monoamine levels were reported at the dopaminergic nerve endings in the striatum, whereas in some other studies decreased DAT and SERT function and damage to dopaminergic/serotonergic nerve endings was observed. Preclinical findings indicate that the adverse effects of synthetic cathinones can often be exacerbated by high temperature and crowded conditions, as in dance club conditions where the drug is used. For this reason, in some neurotoxicity studies, this high ambient temperature $\left(>26^{\circ} \mathrm{C}\right)$ has been imitated. It might be said that the neurotoxicity induced by synthetic cathinones is more 
frequently observed in studies conducted at high temperatures. Since synthetic cathinones are often combined with other cathinone derivatives or noncathinone compounds such as alcohol, amphetamines, ecstasy, and cocaine, it is important to understand the neurotoxic effects in case of polysubstance use. Further research is needed from the toxicological point of view in order to address the health problems associated with bath salts.

Conflict of Interest: No conflict of interest was declared by the authors.

\section{REFERENCES}

1. German CL, Fleckenstein AE, Hanson GR. Bath salts and synthetic cathinones: an emerging designer drug phenomenon. Life Sci. 2014;97:2-8.

2. Zawilska JB, Wojcieszak J. Designer cathinones-an emerging class of novel recreational drugs. Forensic Sci Int. 2013;231:42-53.

3. Gershman JA, Fass AD. Synthetic cathinones ('bath salts'): legal and health care challenges. P T. 2012;37:571-595.

4. Baumann MH, Partilla JS, Lehner KR. Psychoactive "bath salts": not so soothing. Eur J Pharmacol. 2013;698:1-5.

5. Synthetic Cathinones (Bath Salts): An Emerging Domestic Threat (U.S. Department of Justice National Intelligence Center (July 2011)). Retrieved from https://www.justice.gov/archive/ndic/ pubs44/44571/44571p.pdf

6. Katselou M, Papoutsis I, Nikolaou P, Spiliopoulou C, Athanaselis S. प-PVP ("flakka"): a new synthetic cathinone invades the drug arena. Forensic Toxicology. 2015;34:41-50.

7. Vardakou I, Pistos C, Spiliopoulou C. Drugs for youth via Internet and the example of mephedrone. Toxicol Lett. 2011;20:191-195.

8. World Drug Report 2017: 29.5 million people globally suffer from drug use disorders, opioids the most harmful. (2017). Retrieved from https:// www.unodc.org/unodc/en/press/releases/2017/June/world-drugreport-2017_-29-5-million-people-globally-suffer-from-drug-usedisorders--opioids-the-most-harmful.html

9. Capriola M. Synthetic cathinone abuse. Clin Pharmacol. 2013;5:109-115.

10. Kelly JP. Cathinone derivatives: a review of their chemistry, pharmacology and toxicology. Drug Test Anal. 2011;3:439-453.

11. Coppola M, Mondola R. Synthetic cathinones: chemistry, pharmacology and toxicology of a new class of designer drugs of abuse marketed as "bath salts" or "plant food". Toxicol Lett. 2012;211:144-149.

12. de Castro A, Lendoiro E, Fernandez-Vega H, Steinmeyer S, LopezRivadulla M, Cruz A. Liquid chromatography tandem mass spectrometry determination of selected synthetic cathinones and two piperazines in oral fluid. Cross reactivity study with an on-site immunoassay device. J Chromatogr A. 2014;1374:93-101.

13. Glennon RA, Dukat M. Synthetic cathinones: a brief overview of overviews with applications to the forensic sciences. Ann Forensic Res Anal. 2017;4. pii: 1040.

14. Corkery JM Guirguis A, Orsolini L, Papanti D, Schifano F. An investigation into the relationship (s) between the different chemical classes of synthetic cathinones and their effects: desired, adverse, toxic. Paper presented at the UNODC Fifth International Conference on
Novel Psychoactive Substances. United Nations Office on Drugs and Crime (ONODC) Vienna International Centre, Vienna 23-24 October, 2017.

15. Loeffler G, Hurst D, Penn A, Yung K. Spice, bath salts, and the U.S. military: the emergence of synthetic cannabinoid receptor agonists and cathinones in the U.S. Armed Forces. Mil Med. 2012;177:1041-1048.

16. European Drug Report Trends and Developments (European Monitoring Center for Drugs and Drug Addiction 2017). Retrieved from Lüksemburg: http://www.emcdda.europa.eu/system/files/publications/4541/ TDAT17001ENN.pdf

17. 'Zombie' drug seized in Turkey for the first time. (2017 Oct 15). Hürriyet Daily News. Retrieved from http://www.hurriyetdailynews.com/ zombie-drug-seized-in-turkey-for-the-first-time-120896

18. Altun B, Çok I. New pyschoactive substances: synthetic cathinones. J Lit Pharm Sci. 2018;7:136-145.

19. 1-Phenyl-2-(pyrrolidin-1-yl)pentan-1- one ( $\alpha$-PVP) Critical Review Report. (2015 Nov 16-20). Retrieved from Geneva: http://www.who.int/ medicines/access/controlled-substances/5.3_Alpha-PVP_CRev.pdf

20. Banks ML, Worst TJ, Rusyniak DE, Sprague JE. Synthetic cathinones ("bath salts"). J Emerg Med. 2014;46:632-642.

21. Nobrega L, Dinis-Oliveira RJ. The synthetic cathinone alphapyrrolidinovalerophenone (alpha-PVP): pharmacokinetic and pharmacodynamic clinical and forensic aspects. Drug Metab Rev. 2018;50:125-139.

22. Katz DP, Bhattacharya D, Bhattacharya S, Deruiter J, Clark CR, Suppiramaniam V, Dhanasekaran M. Synthetic cathinones: "a khat and mouse game". Toxicol Lett. 2014;229:349-356.

23. Cozzi NV, Sievert MK, Shulgin AT, Jacob P, 3rd, Ruoho AE. Inhibition of plasma membrane monoamine transporters by beta-ketoamphetamines. Eur J Pharmacol. 1999;381:63-69.

24. Fleckenstein AE, Volz TJ, Riddle EL, Gibb JW, Hanson GR. New insights into the mechanism of action of amphetamines. Annu Rev Pharmacol Toxicol. 2007; 47:681-698.

25. Marusich JA, Antonazzo KR, Wiley JL, Blough BE, Partilla JS, Baumann $\mathrm{MH}$. Pharmacology of novel synthetic stimulants structurally related to the "bath salts" constituent 3,4-methylenedioxypyrovalerone (MDPV). Neuropharmacology. 2014;87:206-213.

26. Weinstein AM, Rosca P, Fattore L, London ED. Synthetic cathinone and cannabinoid designer drugs pose a major risk for public health. Front Psychiatry. 2017;8:156.

27. Angoa-Perez M, Anneken JH, Kuhn DM. Neurotoxicology of synthetic cathinone analogs. Curr Top Behav Neurosci. 2017;32:209-230.

28. Thomas DM, Walker PD, Benjamins JA, Geddes TJ, Kuhn DM. Methamphetamine neurotoxicity in dopamine nerve endings of the striatum is associated with microglial activation. J Pharmacol Exp Ther. 2004;311:1-7.

29. Anneken JH, Angoa-Perez M, Kuhn DM. 3,4-Methylenedioxypyrovalerone prevents while methylone enhances methamphetamine-induced damage to dopamine nerve endings: beta-ketoamphetamine modulation of neurotoxicity by the dopamine transporter. J Neurochem. 2015;133:211-222.

30. Hadlock GC, Webb KM, McFadden LM, Chu PW, Ellis JD, Allen $\mathrm{SC}$, Andrenyak DM, Vieira-Brock PL, German CL, Conrad KM, Hoonakker AJ, Gibb JW, Wilkins DG, Hanson GR, Fleckenstein AE. 
4-Methylmethcathinone (mephedrone): neuropharmacological effects of a designer stimulant of abuse. J Pharmacol Exp Ther. 2011;339:530536.

31. Angoa-Perez M, Kane MJ, Briggs DI, Francescutti DM, Sykes CE, Shah MM, Thomas DM, Kuhn DM. Mephedrone does not damage dopamine nerve endings of the striatum, but enhances the neurotoxicity of methamphetamine, amphetamine, and MDMA. J Neurochem. 2013;125:102-110.

32. den Hollander B, Rozov S, Linden AM, Uusi-Oukari M, Ojanpera I, Korpi ER. Long-term cognitive and neurochemical effects of "bath salt" designer drugs methylone and mephedrone. Pharmacol Biochem Behav. 2013;103:501-509.

33. Lopez-Arnau R, Martinez-Clemente J, Pubill D, Camarasa J, Escubedo E. Evidence of neurotoxicity and cognitive impairment induced by methylone in rats. Basic Clin Pharmacol Toxicol. 2014;115:192-193.

34. Lopez-Arnau R, Martinez-Clemente J, Rodrigo T, Pubill D, Camarasa $J$, Escubedo E. Neuronal changes and oxidative stress in adolescent rats after repeated exposure to mephedrone. Toxicol Appl Pharmacol. 2015;286:27-35.

35. Ciudad-Roberts A, Duart-Castells L, Camarasa J, Pubill D, Escubedo E. The combination of ethanol with mephedrone increases the signs of neurotoxicity and impairs neurogenesis and learning in adolescent CD-1 mice. Toxicol Appl Pharmacol. 2016;293:10-20.

36. Naseri G, Fazel A, Golalipour MJ, Haghir H, Sadeghian H, Mojarrad M, Hosseini M, Shahrokhi Sabzevar S, Beheshti F, Ghorbani A. Exposure to mephedrone during gestation increases the risk of stillbirth and induces hippocampal neurotoxicity in mice offspring. Neurotoxicol Teratol. 2018;67:10-17.

37. Prosser JM, Nelson LS. The toxicology of bath salts: a review of synthetic cathinones. J Med Toxicol. 2012;8:33-42.

38. Tarkowski P, Jankowski K, Budzyńska B, Biała G, BoguszewskaCzubara A. Potential pro-oxidative effects of single dose of mephedrone in vital organs of mice. Pharmacol Rep. 2018;70:1097-1104.

39. Valente MJ, Bastos ML, Fernandes E, Carvalho F, Guedes de Pinho P. Carvalho M. Neurotoxicity of beta-keto amphetamines: deathly mechanisms elicited by methylone and MDPV in human dopaminergic SH-SY5Y cells. ACS Chem Neurosci. 2017;8:850-859.

40. Lopez-Arnau R, Martinez-Clemente J, Abad S, Pubill D, Camarasa $J$, Escubedo E. Repeated doses of methylone, a new drug of abuse, induce changes in serotonin and dopamine systems in the mouse. Psychopharmacology (Berl.). 2014;231:3119-3129.
41. Lopez-Arnau R, Martinez-Clemente J, Pubill D, Escubedo E, Camarasa $J$. Serotonergic impairment and memory deficits in adolescent rats after binge exposure of methylone. J Psychopharmacol. 2014;28:10531063.

42. Rosas-Hernandez H, Cuevas E, Lantz SM, Imam SZ, Rice KC, Gannon BM, Fantegrossi WE, Paule MG, Ali SF. 3,4-Methylenedioxypyrovalerone (MDPV) induces cytotoxic effects on human dopaminergic SH-SY5Y cells. Journal of Drug and Alcohol Research. 2016;5:1-6.

43. Rosas-Hernandez H, Cuevas E, Lantz SM, Rice KC, Gannon BM, Fantegrossi WE, Gonzalez C, Paule MG, Ali SF. Methamphetamine, 3,4-methylenedioxymethamphetamine (MDMA) and 3,4-methylenedioxypyrovalerone (MDPV) induce differential cytotoxic effects in bovine brain microvessel endothelial cells. Neurosci Lett. 2016;629:125-130.

44. Angoa-Perez M, Kane MJ, Francescutti DM, Sykes KE, Shah MM, Mohammed AM, Thomas DM, Kuhn DM. Mephedrone, an abused psychoactive component of 'bath salts' and methamphetamine congener, does not cause neurotoxicity to dopamine nerve endings of the striatum. J Neurochem. 2012;120:1097-1107.

45. Martinez-Clemente J, Lopez-Arnau R, Abad S, Pubill D, Escubedo E, Camarasa J. Dose and time-dependent selective neurotoxicity induced by mephedrone in mice. PLoS One. 2014;9:e99002.

46. Richman E, Skoller NJ, Fokum B, Burke BA, Hickerson CA, Cotes RO. $\alpha$-Pyrrolidinopentiophenone ("flakka") catalyzing catatonia: a case report and literature review. J Addict Med. 2018;12:336-338.

47. Crespi C. Flakka-induced prolonged psychosis. Case Rep Psychiatry. 2016;2016:3460849.

48. Nagai H, Saka K, Nakajima M, Maeda H, Kuroda R, Igarashi A, TsujimuraIto $T$, Nara A, Komori M, Yoshida K. Sudden death after sustained restraint following self-administration of the designer drug alphapyrrolidinovalerophenone. Int J Cardiol. 2014;172:263-265.

49. Smith DA, Blough BE, Banks ML. Cocaine-like discriminative stimulus effects of amphetamine, cathinone, methamphetamine, and their 3, 4-methylenedioxy analogs in male rhesus monkeys. Psychopharmacology (Berl.). 2017;234:117-127.

50. Giannotti G, Canazza I, Caffino L, Bilel S, Ossato A, Fumagalli F, Marti M. The cathinones MDPV and alpha-PVP elicit different behavioral and molecular effects following acute exposure. Neurotox Res. 2017;32:594602. 